\title{
Are contextual influences and statutory law empathy impetuses to police attitude to domestic violence against women in Lagos State?
}

\author{
Taofik Olatunji Bankole ${ }^{1^{*}}$ Glory Urhere $^{2}$ \\ ${ }^{1}$ Department of Demography \& Social Statistics, Faculty of Social Sciences, Obafemi Awolowo University, Ile-Ife, Nigeria \\ ${ }^{2}$ Centre for Gender Studies, Obafemi Awolowo University, Ile-Ife, Nigeria
}

\section{Check for updates}

Correspondence to: Taofik Olatunji Bankole, Department of Demography \& Social Statistics, Faculty of Social Sciences, Obafemi Awolowo University, Ile-Ife, Nigeria; E-mail: oluwabamikoleolatunji@gmail.com

Received: March 4, 2021;

Accepted: May 18, 2021;

Published: May 21, 2021.

Citation: Bankole TO and Urhere G. Are contextual influences and statutory law empathy impetuses to police attitude to domestic violence against women in Lagos State? Soc Work Soc Welf, 2021, 3(1): 134-147. https://doi.org/10.25082/SWSW.2021.02.001

Copyright: (C) 2021 Taofik Olatunji Bankole, et al. This is an open access article distributed under the terms of the Creative Commons Attribution License, which permits unrestricted use, distribution, and reproduction in any medium, provided the original author and source are credited.

\begin{abstract}
The Lagos State Statutory (Protection against Domestic Violence) Law was enacted on March 18, 2007 to protect inhabitants of the State against all forms of domestic violence. In spite of the enactment of this law, many inhabitants of Lagos State are still imperiled to emotional, psychological and physical traumas arising from domestic violence. This study validated contextual influences and the understanding of statutory law protecting women against domestic violence in Lagos State. Contextual influences were captured as socio-demographic characteristics, sociocultural and economic factors. The study adopted the quantitative crosssectional research design method. Information was sourced randomly among police personnel across Police Divisions within the State Police Command from July to November, 2019. The Fishers sampling technique was employed to arrive at a sample size of 312 from a total population of 1650 police personnel in Lagos State. Stata version 14 was used in data analysis. The results showed that a biased attitude to domestic violence against women was higher among male (87\%) than female (13\%) police personnel. A biased attitude to domestic violence against women was higher among non-commissioned (65.2\%) than commissioned $(34.5 \%)$ police personnel. Contextual influences such as sociodemographic, sociocultural and economic factors, as well as police understanding of statutory law against domestic violence were found to be significantly associated with police attitude to domestic violence against women in Lagos State. The study concluded that the enactment of the protection against violence law was an appropriate measure to addressing domestic violence, still, the police need to be more proactive and unbiased in handling reported cases of domestic violence against women in the State.
\end{abstract}

Keywords: police, contextual, domestic violence, empathy, statutory law, Lagos State

\section{Introduction}

Three criminal laws exist in Nigeria. The criminal code is pertinent in the South and Penal code and Sharia law in the North. Unlike the Criminal Code and the Sharia law which prohibit domestic violence, the Penal code to large extent permits violence against married women by their husbands. For instance, Section 282 of the Penal code stipulates that a married woman in no circumstance can lay claim to have been raped by husband as long as she is married to him, and such woman has passed through puberty [1]. Likewise, Section 241 of the Penal code stipulates that a married woman can only claim to have been violated if she has been subjected to grievous hurt, where grievous hurt is interpreted as action that could cause permanent injuries to the eyes, body joints, tooth, emasculation, impairments or disfiguration of the face of head [1]. In fact, the Section 55 of the Penal code specifies that a man has the legal right to discipline her wife by beating her if the need arises. The implication of the Penal law is that a married woman in Nigeria, is not only culturally, but also lawfully expected to accept whatever comes her way in her matrimonial home without complaining $[2,3]$.

As posits by [4], prior the judiciary verdict in the case of "Alkamawa Versus Bello" in 1998, that is, LPELRSC2931/1991, the Sharia was classified under a customary law in the country. Henceforth, Sharia is now being recognised as a distinct and acceptable legal system in Nigeria, despite the fact that the legal system in the county is a hybrid of British common and Statutory, Customary and Sharia law [4]. Sharia law is in full operation in twelve (12) out of the nineteen (19) States that make up the Northern region of the country these States are Bauchi, Borno, Gombe, Jigawa, Kaduna, Kano, Katsina, Kebbi, Niger, Sokoto and Zamfara [5]. Sharia law is adhered to in full, in issues relating to personal position, as well as criminal law [1]. Specifically, 
Sharia is applied in personal issues amongst which include inheritance, marriage, divorce and matters relating to Islamic religion doctrines $[1,4]$.

More so, under the Judiciary System of Nigeria, the Sharia Court of Appeals is recognised, and is thereby granted the jurisdiction to review legal cases connecting to Islamic law. As further stated by author, Sharia Court of Appeals in Nigeria equally has the jurisdictions to interpret both the customary and common laws of other regions of the country, including that of the Federal Capital Territory [4]. Based on this, the Sharia Court of Appeals is regarded as the most contentious of the judiciary system. In fact, some scholars argue that the implementation of the Sharia Court of Appeals, as well as the recognition of Sharia in some 12 states of the federation is a violation of the constitution of Nigeria [5].

Largely, many women in Nigeria are frequently subjected to different forms of domestic violence such as physical abuse, sexual abuse, economic abuse, emotional abuse, spiritual abuse and neglect $[6,7]$. In fact, evidence emanating from empirical studies revealed that many women in Nigeria are not only exposed to multiple forms of violence especially in the homes, but are also denied justice when such actions are reported $[1,6,7]$. In the meantime, [1] stated that the most common form of domestic and gender-based violence is wife battery, and this ranges from beating, verbal abuse, and denial of financial resources, rape, and death.

Empirical evidences emanating from contemporary studies revealed that domestic violence, already a leading cause of female injury, deprives women of bodily integrity by eliminating their ability to consent to sex, negotiate safer sex and determine the number and spacing of their children not only in Nigeria but across countries of the world [8-10]. For instance, the rate at which women of reproductive age is exposed to domestic violence one forms or another is uncalled for. According to the reports extracted from the most recent Nigeria Demographic and Health Survey, approximately $25 \%$ of women aged 15 to 49 were subjected to one form of physical domestic violence or another, while about $75 \%$ of married or ever married women in this age group were subjected to economic violence [11]. Furthermore, facts emanating from the survey shows that nearly $25 \%$ of women of reproductive age in Nigeria had suffered domestic violence as a result of sexual demand by their partners [11]. Based on the high prevalence of domestic violence in the country, the Lagos State Law on Domestic Violence came into force on 18 th May 2007.

Policing has always been necessary in all societies for the preservation of order, safety and social relations $[12,13]$. In fact, the necessity of policing becomes even more evident in modern societies characterized by diversities and contradictions arising from population heterogeneity, urbanization, industrialization, conflicting ideologies on appropriate socio-political and economic form of organization $[3,14,15]$. The Police play important roles without which the sustenance of order, legality, development and democracy may be difficult. The primary role of police is policing securing compliance with existing laws and conformity with precepts of social order; but the police are not the only agency involved in policing, in the broad sense of the term $[12,13]$.

Retrospectively, the emergence of the police, a body of men and women recruited and paid by the state to enforce law and maintain order, is a recent development in human history [3] For example, members of the Nigeria Police Force have statutory powers to investigate crimes, to apprehend offenders, to interrogate and prosecute suspects, to grant bail to suspects pending completion of investigation or prior to court arraignment, to serve summons, and to regulate or disperse processions and assemblies [16]. In fact, the Police are empowered to search and seize properties suspected to be stolen or associated with crime, and "to take and record for purposes of identification, the measurements, photographs and fingerprint impressions of all persons in their custody" [16].

Since there is no law against domestic violence in Nigeria, particularly, in many of the Northern States of Nigeria - at best a victim who seeks protection under the law will rely on the provisions of the Criminal Code on common assault [2]. In fact, the Criminal Code considers assault on a woman as a misdemeanor while assault on a man is a felony. This lower sentence of two years means that assault on a woman is not as serious as assault on a man. Victims of domestic violence are reluctant to use the justice system as it is not victim friendly [16]. Women are asked demeaning questions during investigation and trial, and the fear of these intrusive questions about their private lives prevents victims from reporting cases [2]. The current laws do not make adequate provisions for the protection of victims of domestic violence. The victims are usually women and children, and the combination of inadequate laws and male dominated customary and religious practices make the victims more vulnerable, without adequate legal or social remedy [16]. There is therefore a need for a complete overhaul of the criminal justice system in Nigeria using a victim friendly human rights approach.

As contained in the 2007 Lagos State Protection against Violence Law (LAGPAVL) [17], the Police in Lagos State are saddled with the primary responsibility to protect inhabitants 
of the State against all forms of domestic violence [18]. Specifically, 2007 LAGPAVL states that: "a Police officer may without warrant arrest any individual who is reasonably suspected of having committed an offence containing an element of violence against a complainant" [19]. It is further stated that: "whenever a warrant of arrest is forwarded to the Nigeria Police Force in compliance with, a Police Officer shall inform the complainant of his or her right to lay a criminal charge against the respondent" [19]. In 2012, a guideline for Responding to Cases of Violence against Women in Lagos State was implemented. The implementation of the guideline became imperative since its absence would have denied Civil Society Organizations (CSOs) with a standard, recognised and unvarying structure through which they could respond to the needs and supports of survivors of sexual or domestic violence in the country [18].

Specifically, CSOs such as Stand to End Rape (STER), Women at Risk International Foundations (WARIF), Wine and Whine, the Mirabel Centre and Hands-off Initiative are actively fighting against domestic and other related forms of violence against women in Nigeria. Also, national agencies such as the National Centre on Domestic Violence (NCDV), National Agency for the Prohibition of Trafficking in Persons (NAPTIP) were established by the Federal Government, and saddled with the primary responsibilities to fight against domestic violence in Nigeria. More so, faith-based organisations and non-government organisations likewise play active roles in the fight against domestic violence, most especially at the grassroots or rural settings [6]. Notwithstanding how much effort put in by the CSOs, faith-based organisations, among others, the constitutional power to arrest, interrogate and charge suspects or perpetrators of domestic related violence to the court of law still lies in the hands of the Nigeria Police [19]. Ironically, the Police are in most cases found wanting in the discharge of their constitutional responsibilities when issues relating to domestic violence between couples are reported. Perhaps, this uncalled attitude could be attributed to the prevailing traditional beliefs that domestic violence among couples is better resolved amicably between couple at home.

In spite of the weighty role that the law enforcement agencies are assigned with in the prevention of domestic violence, contemporary studies addressing this cruel act across families in Nigeria had rarely explored the extent to which the Police have effectively exercised their constitutional duties in the protection of the people against domestic violence For instance, [6] and [20] were concerned with the patterns and prevalence of domestic violence against pregnant women in Southern Nigeria, rather than the roles played by the Police in bringing the perpetrators of the act to justice. Similarly, [7] had their attention focused on the level of domestic violence that a married woman was subjected to during and after child delivery. Close to the direction of this study were the works of [18] and [1] carried out systematical reviews on the state of family law and the perception of Sharia law in domestic violence in the country, rather than examining the perception or attitude of law enforcement agencies towards domestic violence against women. Hence, there is a dearth of empirical studies that have specifically investigated the role played by the Police is the prevention of domestic violence against married women. This study addressed this limitation by asking this question: are contextual influences (such as socio-demographic characteristics of Police officers, sociocultural and economic factors) and the level of understanding of the 2007 LAGPAVL by the Police impetuses to Police attitude to domestic violence in Lagos State?

\section{Methods}

\subsection{Research design}

The study employed the cross-sectional quantitative explanatory research design, and utilised primary data sourced from the Lagos State Police Commands. And the study employed the quantitative research method, and it adopted the both the descriptive and inferential analytic technique.

\subsection{Setting}

The study was carried out in Lagos State which is home to many police formations like the Lagos State Police Command, Lagos State Police Area Commands, Command Gender desk offices and various police stations, police post and police human right offices. Lagos State Police Command has 13 Police Area Commands. The population for this study comprises all the general duty police officers, Area Crime Officers and Gender Unit Officers/Human Rights Officers/Family unit Officers in the Lagos State Police Command. 


\subsection{Sample}

All the 13 Police Area Commands in Lagos State was purposively selected for the study. The sampling framework used was Fishers sampling formula which gave rise to a sample size of 312 police officers out of a population size of 1,650 police officers in Lagos State.

\subsection{Measurement of variables}

The outcome variable of this study was the police attitude to domestic violence against women in Lagos State, Nigeria. The conceptualisation of domestic violence in this study is restricted to reported forms domestic violence prior the conduction of this survey. The captured domestic violence included but not limited to physical, emotional, sexual and economic psychosocial violence. Police attitude to domestic violence against women was measured twice, and captured differently. For instance, at the univariate level of analysis, Police attitude to domestic violence was measured by categorizing their responses to reported cases of domestic violence into negative, indifferent and positive attitude. Invariably, Police officers who acknowledged that men could violate their wives or partners for one plausible reason or another were captured as those with negative attitude towards domestic violence against women, while those with contrary opinion were captured as those with positive attitude. On the other hand, Police officers who neither had a positive nor a negative attitude were captured as those with indifferent attitude to domestic violence against women. Thus, Police attitude to domestic violence against women is the outcome variable, and it was measured by the aggregation of all the variables in Table 1 Police with negative and indifferent responses were coded as " 0 " and " 1 " respectively, thereby denoting "unbiased attitude" While positive responses were coded as " 2 " thereby denoting "biased attitude" towards domestic violence against women. Since the "binary logistic" can only be derived through the dichotomization of an outcome variable into " 1 " and "0", and supported with the fact that unbiased responses were captured as " 0 " and " 1 " while biased responses were captured as " 2 "; it's therefore necessary to create a separate column where all negative and indifferent responses were then entered as " 0 " while all positive responses were entered as " 1 ". Since, 10 variables were captured in all, the aggregate score was derived - an aggregate score of $<9$ out of a possible total of 20 is coded as " 0 " and labeled as "unbiased attitude" while an aggregate score of 10 and above ( $>9)$ out of a possible 20 is coded as "1" and labeled as "biased attitude"

The explanatory variables of the study were captured as contextual influences and Police empathy of the statutory law. The Contextual influences were captured as socio-demographic factors, economic factors and sociocultural factors. Police empathy of statutory law was captured by examining the extent to which the Lagos State Protection against Violence Law was understood by the Police officers in the State. The socio-demographic characteristics of interest captured in this study included gender, age (male or female), level of educational attainment (secondary or post-secondary school education), marital status (single, married or divorced/separated/widowed), length of years in service ( $>10$ years, 11-20 years or 21 years and above), current rank (non-commissioned officers or commissioned officers) and religious affiliation (Christianity, Islam or Others). Economic influences were measured by asking the respondents if they agreed that economic indices such as poverty, low socio-economic status, unemployment, monetary or household financial demands could influence domestic violence or not. Sociocultural influences were measured by asking the respondents if they agreed that sociocultural factors such male dominance of household wealth, rigidity of gender roles, entrenched structural societal norms, masculinity, acceptance of violence as a way to resolve conflict could cause domestic violence or not. Police empathy of statutory law was captured by examining the level of Police understanding (low or high) of the 2007 Lagos State Protection against Violence Law (LAGPAVL) in the State. In order to measure the "empathy of statutory deeds"; a 6- point Likert scale was developed. Responses were categorised into: $1=\mathrm{I}$ don't know; $2=$ strongly disagree; $3=$ disagree; $4=$ undecided; $5=$ agree and $6=$ strongly agree To derive the level of understanding (empathy) of statutory in relation to respondents' attitude towards domestic violence against women, responses 1, 2, 3 and 4 were collapsed into " 7 " and labeled as "low" while responses 4 and 5 were collapsed into " 8 " and labeled as "high"

\subsection{Data collection}

Primary data were sourced through the administration of the questionnaire. The sourced data were collected across the Lagos State Police Area Commands between July and November, 2019. Both commissioned and non-commissioned police officers, irrespective of their gender or level of education were included in the study. 


\subsection{Data analysis}

The univariate (descriptive) and multivariable level of analysis were carried out using the Stata version 14 software analysis package. At the univariate level of analysis, descriptive statistics - specifically, percentage distributions, mean and standard deviation scores were derived and presented in tables. At the multivariable level of analysis, the binary logistic regression was introduced. The binary logistic regression was considered appropriate due to the way the dependent variable (dichotomization of police attitude to domestic violence into " 1 " if unbiased and "0" if otherwise) while the explanatory variables were categorised. The binary logistic regression was used to determine the coefficient, direction and significance relationship between police attitude to domestic violence and the identified explanatory variables of the study.

Three (3) models were developed with a view to addressing the second objective of the study. In order to achieve the specified objectives, three (3) hypotheses were stated. The first hypothesis stated that police attitude towards domestic violence against women was not significantly related with their socio-demographic characteristics and the economic factors. The second hypothesis stated that police attitude to domestic violence against women was significantly influenced by sociocultural factors. The third hypothesis stated that there was a significant relationship between police officers' understanding of the Lagos State Protection against Violence Law and their attitude towards domestic against women. Model 1 explained the relationship between socio-demographic characteristics, economic influence and police attitude to domestic violence against women, controlling for empathy of statutory law by police and sociocultural influence. Model 2 explained the relationship between sociocultural influence and police attitude to domestic violence against women, holding other explanatory variables of the study constant. In Model 3, we examined the relationship between police empathy of the Lagos State Protection against Violence Law and police attitude to domestic violence against women, controlling for other explanatory variables of the study. The confidence level for the study was fit at $95 \%$. Thus, results were only considered to be significantly associated where p-value was found to be less than 0.05 . Only results that with significance associations were reported in the study.

\section{Results}

The results of Police attitude towards domestic violence against women as indicated in Table 1, a significant proportion of the respondents maintains that on no ground should a husband hit his wife $(1.808 \pm 0.557)$. Deduced from the data above, a significant proportion of the respondents maintain that it is neither appropriate for a husband to hit his wife if she disobeys him (1.734 \pm 0.649$)$ nor hits her if she inquiries whether she keeps girlfriends or not $(1.763 \pm 0.612)$.

Table 1 Distribution of respondents by attitude to domestic violence against women

\begin{tabular}{|c|c|c|c|c|}
\hline \multirow[b]{2}{*}{ Variable } & \multicolumn{4}{|c|}{ Police Attitude to DV against Women } \\
\hline & $\begin{array}{c}\text { Positive } \\
(\%)\end{array}$ & $\begin{array}{l}\text { Indifferent } \\
(\%)\end{array}$ & $\begin{array}{c}\text { Negative } \\
(\%)\end{array}$ & Mean \pm SD \\
\hline Husband has no good reason to hit his wife if she does not complete housework to his satisfaction & $276(88.5)$ & 12(3.9) & $24(7.7)$ & $1.808 \pm 0.557$ \\
\hline Husband has no good reason to hit his wife if she disobeys him & 264(84.6) & $13(4.2)$ & $35(11.2)$ & $1.734 \pm 0.649$ \\
\hline Husband has no good reason to hit his wife if she asks him whether he has other girlfriend & $268(85.9)$ & $14(4.5)$ & $30(9.6)$ & $1.763 \pm 0.612$ \\
\hline Husband has no good reason to hit his wife if she has been unfaithful & $276(88.5)$ & $9(2.9)$ & $27(8.6)$ & $1.798 \pm 0.579$ \\
\hline Husband has no good reason to hit his wife if she goes out without telling him & $234(75.0)$ & $20(6.4)$ & $58(18.6)$ & $1.564 \pm 0.787$ \\
\hline Husband has no good reason to hit his wife if she burns the food & $259(83.0)$ & $12(3.9)$ & $41(13.1)$ & $1.699 \pm 0.689$ \\
\hline Husband has no good reason to hit his wife if she neglects the children & $273(87.5)$ & $12(3.9)$ & $27(8.7)$ & $1.789 \pm 0.584$ \\
\hline Husband has no good reason to hit his wife if she rudely argues with him & $218(69.9)$ & $32(10.3)$ & $62(19.9)$ & $1.500 \pm 0.806$ \\
\hline Husband has no good reason to hit his wife if she argues with her parents-in-law & $252(80.8)$ & $28(8.9)$ & $32(10.3)$ & $1.705 \pm 0.644$ \\
\hline
\end{tabular}

Note: $\mathrm{X}=$ mean; $\mathrm{SD}=$ standard deviation; Minimum = 0; Maximum = 2; Source: Authors' Survey Report 2020

Relatively, three-quarters $(75.0 \%)$ of the respondents admit that husbands have no good reason to hit their wives if such women go out without getting their consent. A significant amount of the respondents argue that a husband has no good reason to hit his wife if his wife is unfaithful to him (1.798 \pm 0.579$)$. More so, a significant proportion of the respondents admits that a husband on no ground should a husband his wife if she burns the food (1.699 \pm 0.689$)$. On the other hand, about one-fifth of the respondents posited that a husband has a good reason to hit his wife if she rudely argues with him $(1.500 \pm 0.806)$. The results likewise show that 
about $10 \%$ of the respondents admits that a husband has good reason to hit his wife if she argues with her parent-in-law. The results, however, show that a high proportion of the respondents is of the view that a husband has no good reason to hit his wife if she neglects the children (1.789 \pm 0.584$)$.

As indicated in Table 2, more than three-quarters (87\%) of the respondents with a biased attitude towards domestic violence against women are male respondents while more than twothirds $(69.6 \%)$ of the respondents with a biased attitude towards domestic violence against women are Police Officers in age bracket 33 to 48 years old. It is evident from that less than half $(47.4 \%)$ of the respondents has post-secondary school qualification. Data from the study reveal that about three-quarters $(73.9 \%)$ of the respondents with a biased attitude towards domestic violence against women are married; while approximately four $(78.2 \%)$ in every five of the respondents with biased attitude towards domestic violence against women are respondents who have not spent more than 20 years in the profession.

Results by Police ranks show that about two-thirds (65.2\%) of the respondents with a biased attitude towards domestic violence against women are respondents whose ranks are below Inspector of Police. About three-quarters (76.0\%) of the respondents are Christians. Results by economic factor show that $47.8 \%$ of the respondents with a biased attitude towards domestic violence against women are Police officer who hold the view that poverty, low socio-economic influence, unemployment and low level of education are predictors of the act. Similarly, more than half $(52.2 \%)$ of the respondents with a biased attitude towards domestic violence against women are Police Officers who agree that monetary and financial demand to meet up with family daily and strategic needs speed up domestic violence against women across various homes.

Table 2 Cross percentage distribution of respondents by sociodemographic characteristics, economic influence and attitude DV against women

\begin{tabular}{|c|c|c|c|}
\hline \multirow{2}{*}{ Variable } & \multicolumn{3}{|c|}{ Police Attitude to DV against Women } \\
\hline & Biased $(\%)$ & Not biased (\%) & $\mathrm{n}=312$ \\
\hline \multicolumn{4}{|l|}{ Socio-demographic characteristics } \\
\hline \multicolumn{4}{|l|}{ Gender } \\
\hline Male & $20(87)$ & 213(73.7) & 233(74.7) \\
\hline Female & $3(13)$ & $76(26.3)$ & $79(25.3)$ \\
\hline \multicolumn{4}{|l|}{ Age (in years) } \\
\hline $18-32$ & $7(30.4)$ & $29(10)$ & $36(11.5)$ \\
\hline $33-48$ & $16(69.6)$ & $239(82.7)$ & $255(81.7)$ \\
\hline $49 \&$ above & $0(0)$ & $21(7.3)$ & $21(6.7)$ \\
\hline \multicolumn{4}{|l|}{ Educational attainment } \\
\hline Secondary school & $16(69.6)$ & $148(51.2)$ & $164(52.6)$ \\
\hline Post-secondary & $7(30.4)$ & $141(48.8)$ & $148(47.4)$ \\
\hline \multicolumn{4}{|l|}{ Marital status } \\
\hline Single & $6(26.1)$ & $31(10.7)$ & $37(11.9)$ \\
\hline Married & $17(73.9)$ & $246(85.1)$ & $263(84.3)$ \\
\hline Divorced/Separated/Widowed & $0(0)$ & $12(14.2)$ & $12(13.8)$ \\
\hline \multicolumn{4}{|l|}{ Length of years in service } \\
\hline $1-10$ years & $9(39.1)$ & $47(16.3)$ & $56(18)$ \\
\hline $11-20$ years & $9(39.1)$ & $183(63.3)$ & $192(61.5)$ \\
\hline 21 years $\&$ above & $5(21.7)$ & $59(20.4)$ & $64(20.5)$ \\
\hline \multicolumn{4}{|l|}{ Current rank } \\
\hline Below Inspector (Non-commissioned Officer) & $15(65.2)$ & 141(49) & $156(50)$ \\
\hline Inspector \& above (Commissioned Officer) & $8(34.8)$ & $148(51)$ & $156(50)$ \\
\hline \multicolumn{4}{|l|}{ Religion } \\
\hline Christianity & $15(65.2)$ & $222(76.8)$ & 237(76) \\
\hline Islam & $8(34.8)$ & $63(21.8)$ & $71(22.8)$ \\
\hline Others & $0(0)$ & $4(1.4)$ & $4(1.4)$ \\
\hline \multicolumn{4}{|l|}{ Economic factor } \\
\hline \multicolumn{4}{|l|}{$\begin{array}{l}\text { Poverty, low socio-economic status, } \\
\text { - unemployment and low level of education } \\
\text { - can be a cause of domestic violence }\end{array}$} \\
\hline Agreed & $11(47.8)$ & $33(11.4)$ & $44(14.1)$ \\
\hline Disagreed & $12(52.2)$ & $256(88.6)$ & $268(85.9)$ \\
\hline \multicolumn{4}{|l|}{$\begin{array}{l}\text { Monetary and financial demand to meet } \\
\text { - daily strategic needs of any member of } \\
\text { - the family can cause DV }\end{array}$} \\
\hline Agreed & $12(52.2)$ & $42(14.5)$ & $54(17.3)$ \\
\hline Disagreed & $11(47.8)$ & $247(85.5)$ & $258(82.7)$ \\
\hline
\end{tabular}

Note: DV = Domestic Violence; Source: Authors' Survey Report 2020

As indicated in Table 3, more than half (52.2\%) of the respondents with biased attitude towards domestic violence against women are Police Officers who agreed that male control of wealth and decision making in the family can induce domestic violence. Also, the results show that at least two $(43.5 \%)$ out of every five respondents with a biased attitude towards domestic 
violence against women are Police Officer who maintained that rigid gender roles promoted domestic violence. Furthermore, about half $(52.2 \%)$ of the respondents with a biased attitude towards domestic violence against women are those who agreed that entrenched structural societal norms promote male dominance against females encourage domestic violence.

More so, the results show that $52.2 \%$ of the respondents with a biased attitude towards domestic violence against women are Police Officers who agreed that the masculinity nature of men drives domestic violence in homes Contrarily, $83.0 \%$ of the respondents with no bias attitude towards domestic violence against women are those that agreed that acceptance of violence is a way to resolve conflict. Relatively, $93.4 \%$ of the respondents with no bias attitude towards domestic violence against women are those who agreed that marital conflict and disharmony influence domestic violence.

Table 3 Cross percentage distribution of respondents by sociocultural influence and police attitude to DV against women

\begin{tabular}{|c|c|c|c|}
\hline \multirow{2}{*}{ Variable } & \multicolumn{3}{|c|}{ Police Attitude to Domestic Violence against Women } \\
\hline & Biased $(\%)$ & Not biased (\%) & $\mathrm{n}=312$ \\
\hline \multicolumn{4}{|c|}{$\begin{array}{l}\text { Male control of wealth and decision making } \\
\text { in the family can be a cause of DV }\end{array}$} \\
\hline Disagreed & $11(47.8)$ & $72(24.9)$ & $83(26.6)$ \\
\hline Agreed & $12(52.2)$ & $217(75.1)$ & $229(73.4)$ \\
\hline \multicolumn{4}{|c|}{ Rigid gender roles can be a cause of DV } \\
\hline Disagreed & $13(56.5)$ & $39(13.5)$ & $52(16.7)$ \\
\hline Agreed & $10(43.5)$ & $250(86.5)$ & $260(83.3)$ \\
\hline \multicolumn{4}{|c|}{$\begin{array}{l}\text { Entrenched structural societal norms which } \\
\text { grant control over female behavior } \\
\text { and actions can cause DV }\end{array}$} \\
\hline Disagreed & 13(47.8) & $52(18.0)$ & $63(20.2)$ \\
\hline Agreed & $12(52.2)$ & $237(82.0)$ & $249(79.8)$ \\
\hline \multicolumn{4}{|c|}{$\begin{array}{l}\text { Notion of masculinity linked to dominance, } \\
\text { honor and aggression can cause DV }\end{array}$} \\
\hline Disagreed & 11(47.8) & $49(17.0)$ & $60(19.2)$ \\
\hline Agreed & $12(52.2)$ & $240(83.0)$ & $252(80.8)$ \\
\hline \multicolumn{4}{|c|}{$\begin{array}{l}\text { Acceptance of violence as a way to resolve as } \\
\text { a way to resolve conflict can cause DV }\end{array}$} \\
\hline Disagreed & $11(47.8)$ & $49(17.0)$ & $60(19.2)$ \\
\hline Agreed & $12(52.2)$ & $240(83.0)$ & $252(80.8)$ \\
\hline \multicolumn{4}{|c|}{ Marital conflict and disharmony can cause DV } \\
\hline Disagreed & $11(47.8)$ & $19(6.6)$ & $30(9.6)$ \\
\hline Agreed & $12(52.2)$ & $270(93.4)$ & 282(90.4) \\
\hline
\end{tabular}

As indicated in Table 4, more than half $(56.5 \%)$ of respondents with a biased attitude towards domestic violence against women are Police Officer with low empathy that the Nigeria Police Gender Policy declaration presents the Police Force as recognizing the negative impacts of gender discriminations and other forms of Gender Based Violence in the society. Contrary to this, about two-thirds (65.2\%) of the respondents with a biased attitude towards domestic violence against women are those with high empathy that the gender policy for the Nigeria Police Force is formulated within the framework of Nigerian Constitution.

Similarly, two in every three $(65.2 \%)$ respondents with a biased attitude towards domestic violence against women are Police Officers with high empathy of the provision for addressing Gender Based Violence as stipulated in the Nigeria Police Gender Policy. The results also show that about one third (34.8\%) of the respondents with a biased attitude towards domestic violence against women are Police Officers with high empathy that the Nigeria Police Gender Policy clarifies the existing Gender Based Violence referral pathway. The results further show that more than half $(56.5 \%)$ of the respondents with a biased attitude towards domestic violence against women are Police Officer with high level of empathy of the existence of the Lagos State domestic violence which prohibits the act against residents of the State.

More than two-thirds (69.6\%) of the respondents with biased attitude towards domestic violence against women are Police Officer with high empathy that they are constitutionally permitted to arrest perpetrators of domestic violence at the scene of the act. on the other hand, at least two $(43.5 \%)$ in every five respondents with a biased attitude towards domestic violence against women are Police Officers with low empathy that they ought to assist a domestic violence victim to obtain an order from the court of law if the need for such arises. Likewise, about $44 \%$ of the respondents with biased attitude towards domestic violence against women are Police Officer with low empathy that they are empowered to assist victim to find a suitable shelter and to obtain medical treatment if found necessary. 
Table 4 Cross percentage distribution of respondents by empathy and attitude to DV against women

\begin{tabular}{|c|c|c|c|}
\hline \multirow{2}{*}{ Variable } & \multicolumn{3}{|c|}{ Police Attitude to Domestic Violence against Women } \\
\hline & Biased $(\%)$ & Not biased $(\%)$ & $\mathrm{n}=312$ \\
\hline \multicolumn{4}{|c|}{$\begin{array}{l}\text { The NPGP declaration presents the NPF } \\
\text { as recognizing the negative impacts of GD, } \\
\text { sexual harassment, DV and other forms of } \\
\text { GBV in the society }\end{array}$} \\
\hline Low & $13(56.5)$ & $25(8.7)$ & $38(12.2)$ \\
\hline High & $10(43.5)$ & 264(91.4) & $274(87.8)$ \\
\hline \multicolumn{4}{|c|}{$\begin{array}{l}\text { The GP for the NPF is formulated } \\
\text { within the framework of the NC } \\
\text { which guarantees equality and right } \\
\text { to freedom from discrimination }\end{array}$} \\
\hline Low & $8(34.8)$ & 19(6.6) & $27(8.7)$ \\
\hline High & $15(65.2)$ & 270(93.4) & 285(91.4) \\
\hline \multicolumn{4}{|c|}{$\begin{array}{l}\text { NPGP GBV in Nigeria provide a directory } \\
\text { of service providers who can be } \\
\text { contacted in cases where DV has occurred }\end{array}$} \\
\hline Low & $8(34.8)$ & $56(19.4)$ & $64(20.5)$ \\
\hline High & $15(65.2)$ & 233(80.6) & $248(79.5)$ \\
\hline \multicolumn{4}{|c|}{ NGFS clarifies existing GBV referral pathway } \\
\hline Low & $15(65.2)$ & $62(21.5)$ & $77(24.7)$ \\
\hline High & $8(34.8)$ & 227(78.6) & $235(75.3)$ \\
\hline \multicolumn{4}{|c|}{$\begin{array}{l}\text { Lagos State DV law states that any } \\
\text { member of the Nigeria police, shall, } \\
\text { at the scene of DV assist and inform } \\
\text { complainant of their rights }\end{array}$} \\
\hline Low & $10(43.4)$ & $21(7.3)$ & $31(9.9)$ \\
\hline High & $13(56.5)$ & 268(92.7) & 281(90.1) \\
\hline \multicolumn{4}{|c|}{$\begin{array}{l}\text { A Police Officer may without warrant } \\
\text { arrest any respondent at the scene of an } \\
\text { incident of DV whom he or she RS } \\
\text { of having C \& O containing an element } \\
\text { of violence against a complainant }\end{array}$} \\
\hline Low & $7(30.4)$ & $16(5.5)$ & $23(7.4)$ \\
\hline High & $16(69.6)$ & 273(94.5) & $289(92.6)$ \\
\hline \multicolumn{4}{|c|}{$\begin{array}{l}\text { GRC of VAW in Lagos State is } \\
\text { to provide (CSOs) that assist and support victims } \\
\text { of GB violence with a SF for responding to } \\
\text { the needs of victims }\end{array}$} \\
\hline Low & $12(52.2)$ & $25(8.6)$ & $37(11.9)$ \\
\hline High & $11(47.8)$ & 264(91.4) & $275(88.1)$ \\
\hline \multicolumn{4}{|c|}{$\begin{array}{l}\text { The Police Officer should assist a DV } \\
\text { victim to obtain a protection order } \\
\text { from the court if necessary }\end{array}$} \\
\hline Low & $10(43.5)$ & $23(8.0)$ & $33(10.6)$ \\
\hline High & $13(56.5)$ & $266(92.0)$ & $279(89.4)$ \\
\hline \multicolumn{4}{|c|}{$\begin{array}{l}\text { A Police Officer shall assist victim } \\
\text { to find a suitable shelter and } \\
\text { to obtain medical treatment }\end{array}$} \\
\hline Low & $10(43.4)$ & $41(14.2)$ & $51(16.4)$ \\
\hline High & $13(56.5)$ & $248(85.8)$ & 261(83.7) \\
\hline
\end{tabular}

Table 5 presents the results of the binary ordinal logistic regression. As indicated in Model 1, respondents within age bracket 33 to 48 years were found to be 3.6 times likely to demonstrate a positive attitude towards domestic violence against women than their counterparts in age group 18 to 32 years $(\mathrm{OR}=3.61 ; \mathrm{p}=0.009)$. Results by marital status showed that married respondents were found to be 2.5 likely to exhibit a positive attitude towards domestic violence against women than unmarried respondents $(\mathrm{OR}=2.8 ; \mathrm{p}=0.044)$. Also, the results showed that respondents who had spent more than twenty years in service were found to be 2.3 times likely to demonstrate a positive attitude to handling cases of domestic violence towards women than those who had on the job for less than 11 years $(O R=2.26 ; p=0.166)$. The results further showed an existence of a significant association between socio-demographic characteristics of the respondents and their attitude towards domestic violence against women $(\mathrm{p}<0.05)$.

The results further showed that there was a significant association between socio-demographic characteristics of police officers and their attitude towards domestic violence against women in Lagos State, Nigeria $(\mathrm{p}<0.05)$. Results by economic influence showed that respondents who disagreed that poverty, low socio-economic status, unemployment and low level of education could be a cause of domestic violence were found to be 7.1 times likely to demonstrate positive attitude towards domestic violence against women than their counterparts with contrary view $(\mathrm{OR}=7.11 ; \mathrm{p}=0.000)$. Equally, respondents who disagreed that monetary and financial demand 
Table 5 Results of Binary logistic regression showing association between identified independent variables and outcome variable (Police attitude to DV against women)

\begin{tabular}{|c|c|c|}
\hline Socio-demographic Characteristics (Model I) & Odd Ratio & p-value \\
\hline \multicolumn{3}{|l|}{ Age } \\
\hline $18-32$ years $R C$ & 1.000 & \\
\hline $33-48$ years & 3.606 & $0.009 * *$ \\
\hline \multicolumn{3}{|l|}{ Length of years in service } \\
\hline $1-10$ years ${ }^{R C}$ & 1.000 & \\
\hline $11-20$ years & 3.894 & $0.006 * *$ \\
\hline$>21$ years & 2.259 & 0.168 \\
\hline \multicolumn{3}{|l|}{ Marital status } \\
\hline Single ${ }^{R C}$ & 1.000 & \\
\hline Married & 2.801 & $0.044 *$ \\
\hline \multicolumn{3}{|l|}{ Economic Influence } \\
\hline \multicolumn{3}{|c|}{$\begin{array}{l}\text { Poverty, low socio-economic status, unemployment and } \\
\text { low level of education can be a cause of DV }\end{array}$} \\
\hline Agreed $^{R C}$ & 1.000 & \\
\hline Disagreed & 7.111 & $0.000 * * *$ \\
\hline \multicolumn{3}{|c|}{$\begin{array}{l}\text { Monetary and financial demand to meet daily strategic needs of } \\
\text { any member of the family can cause DV }\end{array}$} \\
\hline Agreed $^{R C}$ & 1.000 & \\
\hline Disagreed & 6.416 & $0.000 * * *$ \\
\hline \multicolumn{3}{|l|}{ Sociocultural Influence (Model II) } \\
\hline \multicolumn{3}{|c|}{$\begin{array}{l}\text { Male control of wealth and decision making in the family } \\
\text { can be a cause of DV }\end{array}$} \\
\hline Disagreed $^{R C}$ & 1.000 & \\
\hline Agreed & 2.763 & $0.021 *$ \\
\hline \multicolumn{3}{|l|}{ Rigid gender roles can be a cause of DV } \\
\hline Disagreed $^{R C}$ & 1.000 & \\
\hline Agreed & 8.333 & $0.000 * * *$ \\
\hline \multicolumn{3}{|c|}{$\begin{array}{l}\text { Entrenched structural societal norms which grant control } \\
\text { over female behavior and actions can cause DV }\end{array}$} \\
\hline Disagreed $^{R C}$ & 1.000 & \\
\hline Agreed & 4.663 & $0.001 * *$ \\
\hline \multicolumn{3}{|l|}{$\begin{array}{l}\text { Notion of masculinity linked to dominance, honor } \\
\text { and aggression can cause DV }\end{array}$} \\
\hline Disagreed $^{R C}$ & 1.000 & \\
\hline Agreed & 4.178 & $0.001 * *$ \\
\hline \multicolumn{3}{|c|}{$\begin{array}{l}\text { Acceptance of violence as a way to resolve as a way } \\
\text { to resolve conflict can cause DV }\end{array}$} \\
\hline Disagreed $^{R C}$ & 1.000 & \\
\hline Agreed & 4.489 & $0.001 * *$ \\
\hline \multicolumn{3}{|l|}{ Marital conflict and disharmony can cause DV } \\
\hline Disagreed $^{R C}$ & 1.000 & \\
\hline Agreed & 13.026 & $0.000 * * *$ \\
\hline \multicolumn{3}{|l|}{ Empathy of Statutory Deeds (Model III) } \\
\hline \multicolumn{3}{|c|}{$\begin{array}{l}\text { The NPGP declaration presents the NPF as recognizing } \\
\text { the negative impacts of GD, sexual harassment, DV in the society }\end{array}$} \\
\hline Low $R C$ & 1.000 & \\
\hline High & 7.579 & $0.000 * * *$ \\
\hline \multicolumn{3}{|c|}{$\begin{array}{l}\text { The GP for the NPF is formulated within the framework } \\
\text { of the NC which guarantees equality and right } \\
\text { to freedom from discrimination }\end{array}$} \\
\hline Low $^{R C}$ & 1.000 & \\
\hline High & 13.728 & $0.000^{* * *}$ \\
\hline \multicolumn{3}{|c|}{$\begin{array}{l}\text { NGFS on GBV in Nigeria provide a directory of service } \\
\text { providers who can be contacted on cases relating to DV }\end{array}$} \\
\hline Low $^{R C}$ & 1.000 & \\
\hline High & 6.865 & $0.000 * * *$ \\
\hline $\begin{array}{l}\text { Lagos State DV law states that any member of } \\
\text { shall, at the scene of DV assist and inform com }\end{array}$ & & \\
\hline Low $^{R C}$ & 1.000 & \\
\hline High & 9.817 & $0.000 * * *$ \\
\hline $\begin{array}{l}\text { A Police Officer may without warrant arrest an } \\
\text { at the scene of an incident of DV whom he or s } \\
\text { an element of violence against a complainant }\end{array}$ & & \\
\hline Low $^{R C}$ & 1.000 & \\
\hline High & 11.520 & $0.000 * * *$ \\
\hline $\begin{array}{l}\text { GRC of VAW in the State is to provide (CSOs) } \\
\text { of GB violence with a SF for responding to vic }\end{array}$ & & \\
\hline Low $R C$ & 1.000 & \\
\hline High & 7.464 & $0.000 * * *$ \\
\hline $\begin{array}{l}\text { The Police Officer should assist a DV victim to } \\
\text { protection order from the court if necessary }\end{array}$ & & \\
\hline Low $^{R C}$ & 1.000 & \\
\hline High & 8.896 & $0.000 * * *$ \\
\hline $\begin{array}{l}\text { A Police Officer shall assist victim to find } \\
\text { a suitable shelter and to obtain medical treatme }\end{array}$ & & \\
\hline Low $^{R C}$ & 1.000 & \\
\hline High & 4.653 & $0.001 * *$ \\
\hline
\end{tabular}

Note: $*$ Significant at $\mathrm{p}<0.05,{ }^{*}$ Significant at $\mathrm{p}<0.01,{ }^{* * *}$ Significant at $\mathrm{p}<0.001 ; \mathrm{RC}$ (Reference category) 
to meet daily and strategic needs of any member of the family can cause domestic violence were found to be 6.42 likely to exhibit a positive attitude towards domestic violence against women than respondents with a opposite view $(\mathrm{OR}=6.42 ; \mathrm{p}=0.000)$. The results further showed that there was a significant association between economic influence and police attitude towards domestic violence against women in Lagos State, Nigeria $(\mathrm{p}<0.05)$.

As indicated in Model 2, respondents who agreed that male control of wealth and decision making in the family could be a cause of domestic violence were 2.8 times likely to demonstrate a positive attitude towards domestic violence against women than those with a contrary view $(\mathrm{OR}=2.76 ; \mathrm{p}=0.021)$. Also, the results showed that respondents who agreed that rigid gender roles could be a cause of domestic violence were 8.3 times likely to exhibit a positive attitude towards domestic violence against women than their counterparts with a contrary view $(\mathrm{OR}=$ 8.33; $\mathrm{p}=0.000)$. Likewise, the results showed that respondents who agreed that entrenched structural societal norms which granted control over female behaviour and action could cause domestic violence were found to be 4.7 times likely to demonstrate a positive attitude towards domestic violence against women than those who held a contrary view $(O R=4.67 ; \mathrm{p}=0.001)$. Also, respondents who agreed that notion of masculinity linked to dominance, honour and aggression could cause domestic violence were found to be 4.2 times likely to demonstrate a positive attitude towards domestic violence against women than respondents who disagreed with the view $(\mathrm{OR}=4.18 ; \mathrm{p}=0.001)$.

More so, the results showed that respondents who agreed that acceptance of violence as a way to resolving conflict could cause domestic violence were 4.5 times likely to show a positive attitude towards domestic violence against women than their counterparts with a contrary view concerning the subject matter $(\mathrm{OR}=4.49 ; \mathrm{p}=0.001)$. The results also showed that respondents who agreed that marital conflict and disharmony could cause domestic violence were found to be 13 times likely to exhibit a positive attitude towards domestic violence against women compared to those with contrary view on the subject matter $(O R=13.03 ; p=0.000)$. The results further showed that there was significant association between sociocultural influence and police attitude towards domestic violence against women in Lagos State, Nigeria $(\mathrm{p}<0.05)$.

As indicated in Model 3, respondents who held a high perception that the NPGP declaration presents the NPF as recognizing the negative impacts of GD, sexual harassment, domestic and other forms of gender based violence in the society were found to be 7.6 times likely to exhibit a positive attitude towards domestic violence against women than respondents with low view $(\mathrm{OR}=7.58 ; \mathrm{p}=0.000)$. Results showed that respondents who held a high view that the GP for the NPF is formulated within the framework of the NC which guarantees equality and right to freedom from discrimination were found to be 13.7 times likely to demonstrate a positive attitude towards domestic violence against women than their counterparts who held a low view $(\mathrm{OR}=13.73 ; \mathrm{p}=0.000)$. Also, the results showed that respondents who held a high perception that NGFS on GBV in Nigeria provide a directory of service providers who could be contracted in cases where domestic violence had occurred were found to be 6.9 times likely to exhibit a positive attitude towards domestic violence against women than those who held low perception on the subject matter $(\mathrm{OR}=6.87 ; \mathrm{p}=0.000)$.

Likewise, the results showed that respondents who held a high perception that Lagos State domestic violence law stated that any member of the Nigeria police, shall, at the scene of Domestic violence assist and informed complaint of their rights were found to be 9.8 times likely to demonstrate a positive attitude towards domestic violence than respondents who held a low view $(\mathrm{OR}=9.82 ; \mathrm{p}=0.000)$. Similarly, the results showed that respondents who held a high perception that GRC of VAW in Lagos State was to provide CSOs that assisted and supported victims of GB violence with a SF for responding to the needs of victims were found to be 7.5 times likely to demonstrate a positive attitude towards domestic violence against women than respondents who held a low view on the subject matter $(\mathrm{OR}=7.46 ; \mathrm{p}=0.000)$.

The results also showed that respondents who held a high view that a police officer should assist victim to find a suitable shelter and to obtain medical treatment were found to be 4.7 times likely to demonstrate positive attitude towards domestic violence against women than those with a low level of perfection on the subject matter $(O R=4.65 ; p=0.001)$. The results further showed that there was a significant association between police empathy of statutory deeds and their perception towards domestic violence against women in Lagos State, Nigeria $(\mathrm{p}<0.05)$.

\section{Discussion}

The study examined contextual factors and statutory deed empathy as impetuses to police attitude to domestic violence against women in Lagos State, Nigeria. Evidence from our study revealed that the attitude of some of the Lagos State Police personnel towards domestic violence 
against women was undesirable. For instance, we observed that nearly one-fifth $(18.6 \%)$ of the interviewed police personnel were not totally against the battering of a married woman went out of her matrimonial home without the permission of her husband or partner. Conspicuously, it was evident from our study that approximately $20 \%$ of the interviewed police officers supported the battering of a married woman who behaved rudely to her husband. Our findings were in line with $[21,22]$ who noted that domestic violence against women at home sometimes was stimulated by trivialities that could be handled amicably. Similarly, our findings collaborated with [16] who suggested that the need for the reformation of the Nigerian criminal law in order to address the rise in domestic violence against women and the girl child in the country. Based on the aforementioned, it is imperative for the Nigerian government to address the identified lapses in the Penal law which permits domestic violence against married women. In fact, the penal code, just as both the criminal and sharia law do not permit domestic violence should be restructured in so a way that it will permit zero tolerance against domestic violence, and thereby protect women against this inhumane act against married women.

Another major discovery in this study is the admission of police officers in the studied area that domestic violence was unavoidable in a poverty-stricken household. The interviewed police personnel argued that domestic violence was a typical incidence in the households where the husbands could not caretaker for the needs of their homes. In fact, evidence from our study revealed that the in ability of men to meet the monetary or financial needs of their partners was the major cause of domestic violence against women in many of these households Retrospectively, the biasness of Police Personnel to handling domestic violence against women in a proper way could be attributed to their mindsets that domestic violence in imminent in a poor household. Our findings are in line with [2, 7, 16,23]. For instance, [23] noted that many women tried as much as possible to stay in an abusive relationship all because of their children, while $[2,7,20]$ identified economic constraints, financial burdens and frustration as a result of household poverty as some of the leading factors that influenced domestic violence in Nigeria.

One of our key discoveries in this study is that our respondents maintained that the fact that the predominant patriarch nature of the Nigerian society somewhat made it difficult to punish perpetrators of domestic violence against women appropriately. Thus, it is imperative from our findings that sociocultural influences remain some of the major primary factors that permit the act of domestic violence against women in Lagos State. For example, evidence from our study revealed that entrenched structural societal norms, male control of household wealth, and less engagement of women in household decision making, and the traditional conformity to biased and rigid gender roles make married women to be more susceptible to domestic violence against women in the State. Perhaps, the subjection of women to domestic and other related violence may become relatively higher until the aspect of the culture that gives the male folk precedence over the female folk is eliminated, while equity, justice and fairness is upheld irrespective of gender. Contrary to our findings, [24-28] were of the opinion that rather than fighting against the violation of women at home, women should also be taught of different measures that could enable them to cope or survive in an abusive relationship.

Evidence from our study strongly established the existence of a significance relationship between police understanding of statutory law (the 2007 LAGPAVL) and their attitude to domestic violence against women. One of our key discoveries in this study is that the police attitude to domestic violence was relatively biased despite having a good knowledge of the 2007 LAGPAVL. There is no doubt that the signing of the gender based violence bill into law is an appropriate measure to containing the perpetrators of the act, nevertheless, the expected decline in prevalence rate of domestic violence against women will remain relatively high, for a long time except, and only if the Police and the Judiciary discharge their constitutional duties as stipulated in the 2007 LAGPAVL Consistently, findings emanating from our study validated $[3,17,29]$ who argued that many perpetrators of domestic violence against were neither apprehended nor indicted due to the limited supports coming from the law enforcement agencies. More so, our findings also buttressed [6] who reiterated that it was culturally expected of a married woman in Nigeria to accept whatever came her way in her matrimonial home without complaining. Empirical facts emanating from our study corroborated [30-32] who posited in their review that there were no concrete measures in place to assist victims of domestic violence, especially in the developing regions of the world. More so, our findings substantiated [33] who were soliciting for a globally recognized attitude to addressing and containing the act of domestic violence against women and the girl-child across all nations of the world.

Previous studies validated the absence of functional or shortcomings in domestic violence laws as the major factors influencing domestic violence in many countries, especially those in the developing regions of the world [3,12,17,33,34]. The incidence of domestic violence against women is relatively rampant in many developing countries due to the predominance of the patriarchal family system, where social norms and values relating to family and marriage 
are strongly upheld $[6,21,24]$. Unlike previous studies, our study contributes to the existing body of knowledge in a unique way. For instance, we discovered that the Police Officers who are supposed to apprehend perpetrators of domestic violence, even without warrant as contained in the Lagos State "Protection against Violence Law" are not proactive in the discharge of their constitutional duties due to their conformity to the prevailing social norms and beliefs about family and marriage which suggest amicable resolution between partners. Also, we discovered that the inability of some Police Officers to fully comprehend the "Protection against Violence Law" is deterring the Lagos State Government from actualising its goal to curbing the occurrence domestic violence in the State. It is imperative that Police Officers separate themselves from barbaric culture and societal norms that make them see domestic violence as an act that could be settled amicably at homes rather than seeing the act as a violation of human dignity.

On the other hand, the study moved beyond the conventional attitude to describing the incidence of domestic violence in the studied area and the country as a whole. Nevertheless, the inability of the study to employ the mixed-method attitude restricted it from exploring cultural and religious doctrinal influences on the Police attitude to domestic violence against women in the study area.

\section{Conclusion}

This study examined the attitude of police personnel in Lagos State, Nigeria to domestic violence against women. It further established police empathy of the Lagos State Protection against Violence Law and contextual influences, which included police socio-demographic, economic and sociocultural factors as predictors of police attitude to domestic violence against women Lagos State. Overtly, the act of domestic violence against women in Lagos State, Nigeria is on the rise, and it is imperative that the appropriate urgent measures are taken. It is evident from this study that the Police have much to contribute to containing the rising in the incidence of domestic violence across households in the country. Therefore, the study concluded that the signing of the Protection against Violence bill into law in Lagos State would bring about a significant drop in the incidence, where the Police fail in their duties to fully enforce the law.

\section{Policy recommendations}

Based on the evidence from the study, the following recommendations were provided to address the issues of domestic violence:

(1) Also, effort should also be made to have female officers represented at the top ranks in the Police Force like the ranks of Commissioners, Assistant Inspector General of Police, Deputy Inspector General of Police and even the position of the Inspector General of Police. The adequate representation of women in the NPF is a developmental goal and it should be given the priority and the seriousness it deserves.

(2) The high proportion of police officers who were respondents in Lagos State were aware and understood state guidelines, policies and laws use in combating domestic violence. This is related with the findings that almost half of the respondents had completed tertiary education. It is recommended that police authorities should raise the educational entry qualifications for the force. Officers who were already recruited and serving should be encouraged to acquire higher degrees and certificates. This will go a long way in enhancing their awareness of policies in general and domestic violence polices guidelines and laws in particular. Also, awareness campaign on domestic violence policies, guidelines and laws should be continuous and intensified to keep at abreast with new ones.

(3) The 2010 Nigeria Policy Gender Policy in regards to inculcating domestic violence training into the training curriculum of the fresh recruit at the Policy Academy and Police Collages should be implemented. This is because the officers that have received training on domestic violence did not get such trainings as fresh recruits into the Police Academy since it was not in the training curriculum. Police Officers should be trained on how to earn public trust. This will improve their skills and enhance their efficiency.

(4) Effort should be intensified to have zero tolerance to negative attitude against domestic violence through orientation and re-orientation, trainings, seminars and workshops. Attitude comprises of belief, norms and values that forms individual behaviour. It is a social construction. It is dynamic and not static. It can be deconstructed and reconstructed to reflect zero tolerance for negative attitude towards domestic violence. 


\section{Conflict of interest and funding}

The authors state that they have no conflicting interests.

\section{Acknowledgements}

The authors express appreciation to the Nigeria Police, Lagos State Police Command for granting us the right to carry out the research among its personnel.

\section{References}

[1] Umar MA. The perception of Shari'ah on domestic violence. Nnamdi Azikiwe, University Journal of International Law and Jurisprudence, 2012, 3: 170-181. https://www.ajol.info/index.php/naujilii/article/downlaod/136363/125854

[2] Ajah O, Iyoke A, Nkwo O, et al. Comparison of domestic violence against women in urban versus rural areas of Southeast Nigeria. International Journal of Women's Health, 2014, 6: 865-872. http://doi.org/10.2147/IJWH.S70706

[3] Campbell M, Hicks R, Thompson S, et al. Characteristics of Intimate Partner Violence incidents and the environments in which they occur: victim reports to responding law enforcement officers Journal of Interpers. Violence. 2017. https://doi.org/10.1177/0886260517704230

[4] Oba AA. Islamic Law as Customary Law: The Change Perspective in Nigeria. The International and Comparative Law Quarterly, 2020, 51(4): 817-850. https://doi.org/10.1093/iclq/51.4.817.JSTOR3663189

[5] British Broadcasting Corporation [BBC] (2002). "Nigeria Sharia architect defends law". Retrieved on May 3, 2021, BBC News. 21 March, 2002. news.bbc.co.uk/1/hi/world/Africa/1885052.stm.

[6] Ayodapo O, Sekoni O and Asuzu C. Pattern of intimate partner violence disclosure among pregnant women attending ante-natal clinic in Oyo East Local Government, Nigeria. South African Family Practice, 2017, 59(2): 67-71.

[7] Ezeudu C, Akpa O, Waziri E, et al. Prevalence and correlates of intimate partner violence, before and during pregnancy among attendees of maternal and child health services, Enugu, Nigeria: mixed method attitude, January 2015. The Pan African medical journal, 2019, 32(Suppl 1): 14. https://doi.org/10.11604/pamj.supp.2019.32.1.13287

[8] IRIS Domestic Violence Center (2015) Domestic Violence Statistics [www]. http://www.stopdv.org/index.php/statistics/

[9] Laelago T, Belachew T and Tamrat M. Effect of intimate partner violence on birth outcomes. African Journal of Health Sciences, 2017, 17(3): 681-689. https://doi.org/10.4314/ahs.v17i3.10

[10] Swailes L, Lehman B and McCall-Hosenfeld S. Intimate partner violence discussion in the healthcare setting: A cross-sectional study. Preventive Medicine Reports, 2017, 8: 215-220. https://doi.org/10.1016/j.pmedr.2017.10.017

[11] NPopC and ICF Macro. Nigeria Demographic and Health Survey. Abuja, Nigeria, and Rockville, Maryland, USA. 2019.

[12] Campbell M, Thompson L, Harris A, et al. Intimate partner violence and pet abuse: responding law enforcement officers' observations and victim reports from the scene. Journal of Interpers. Violence, 2018. https://doi.org/10.1177/0886260518759633

[13] McGirr A and Sullivan M. Critical Consciousness Raising as an Element of Empowering Practice with Survivors of Domestic Violence. Journal of Social Service Research, 2017, 43(2): 156-168. https://doi.org/10.1080/01488376.2016.1212777

[14] Catal-Miana A, Lila M, Oliver A, et al. Contextual factors related to alcohol abuse among intimate partner violence offenders Subst. Use Misuse, 2017, 52(3): 294-302. https://doi.org/10.1080/10826084.2016.1225097

[15] Hamberger K, Rhodes K and Brown J. Screening and intervention for intimate partner violence in healthcare settings: creating sustainable system-level programs. Journal of Women's Health, 2015 , 24(1): $86-91$ https://doi.org/10.1089/jwh.2014.4861

[16] Eze-Anaba. Domestic Violence and Legal Reforms in Nigeria: Prospects, 2010 https://www.lawandgender.com/eze-anaba.pdf.

[17] McCleary-Sills J, Namy S, Nyoni J, et al. Stigma, shame and women's limited agency in help-seeking for intimate partner violence. Global Public Health, 2016, 11(1-2): 224-235. https://doi.org/10.1080/17441692.2015.1047391

[18] Nwogugu I. Family law in Nigeria, HEBN Publishers Plc. Ibadan, Nigeria. 2014. https://data.unicef.org/topic/child-protection/violence/domesticviolence-unicef-irc 
[19] Lagos State Protection against Violence Law [LAGPAVL] (2007). Retrieved on August 24, 2020 from: https://learningpartnership.org/index.php/resource/domestic-prevention-law-lagos-state-nig eria-document-english

[20] Ashimi O and Amole G. Prevalence \& predictors for domestic violence among pregnant women in a rural community Northwest, Nigeria. Nigerian medical journal: journal of the Nigeria Medical Association, 2015, 56(2): 118-121.

https://doi.org/10.4103/0300-1652.150696

[21] Stopler G. "A Rank Usurpation of Power" the Role of Patriarchal Religion and Culture in the Subordination of Women, Duke Journal of Gender Law and Policy 365-398. 1998. https://www.scholarship.law.duke.edu/djglp/vol15/iss1/5

[22] Sullivan M. Examining the Work of Domestic Violence Programs Within a "Social and Emotional Well-Being Promotion" Conceptual Framework, Harrisburg, PA: National Resource Centre on Domestic Violence, 2012. http://www.dvevidenceproject.org

[23] Alexandra J and Arlene V. You just deal with it. You have to when you have got a child A narrative analysis of mothers' accounts of how they coped, both during an abusive relationship and after leaving, Clinical Child Psychology and Psychiatry, 2017, 22(1): 74-89. https://doi.org/10.1177/1359104515624131

[24] Azene N, Yeshita Y and Mekonnen A. Intimate partner violence and associated factors among pregnant women attending antenatal care service in Debre Markos town health facilities, Northwest Ethiopia. PLoS ONE, 2019, 14(7): e0218722. https://doi.org/10.1371/journal.pone.0218722

[25] Decker R, Nair S, Saggurti N, et al. Violence-related coping, help-Seeking \& health care-based intervention preferences among perinatal women in Mumbai, India. Journal of Interpersonal, 2013, 28(9): 1924-1947. https://doi.org/10.1177/0886260512469105

[26] Islam J, Broidy L, Baird K, et al. Intimate partner violence around the time of pregnancy and postpartum depression: The experience of women of Bangladesh. PLOS ONE, 2017, 12(5): e0176211. https://doi.org/10.1371/journal.pone.0176211

[27] Suryavanshi N, Naik S, Waghmare S, et al. Gender-based violence screening methods preferred by women visiting a public hospital In Pune, India. BMC Women's Health, 18. 2018. http://doi.org/10.1186/s12905-018-0515-2

[28] Tonsing J and Barn R. Intimate partner violence in South Asian communities: Exploring the notion of "shame" to promote understandings of migrant women's experiences. International Social Work, 2017, 60(3): 628-639. https://doi.org/10.1177/0020872816655868

[29] Tirado-Muoz J, Gilchrist G, Farr M, et al. The efficacy of cognitive behavioural therapy and advocacy interventions for women who have experienced intimate partner violence: a systematic review and meta-analysis. Annals of Medicine, 2014, 46(8): 567-586. https://doi.org/10.3109/07853890.2014.941918

[30] Ellsberg M and Heise L. Researching Violence against Women: A Practical Guide for Researchers and Activists [www]. 2005 http://whqlibdoc.who.int/publications/2005/9241546476_eng.pdf?ua=1

[31] Van Parys S, Verhamme A, Temmerman M, et al. Intimate Partner Violence and Pregnancy: A Systematic Review of Interventions. PLoS ONE, 2014, 9(1): e85084. https://doi.org/10.1371/journal.pone.0085084

[32] Wang T, Liu Y, Li Z, et al. Prevalence of intimate partner violence (IPV) during pregnancy in China: A systematic review and meta-analysis. PloS One, 2017, 12(10): e0175108.

[33] Vu A, Wirtz L, Bundgaard S, et al. Feasibility and acceptability of a universal screening and referral protocol for Gender Based Violence with women seeking care in health clinics in Dadaab refugee camps in Kenya. Global Mental Health, 4. 2017. https://doi.org/10.1017/gmh.2017.18

[34] Haeseler A. Women's coping experiences in the spectrum of domestic violence abuse. Journal of Evidence-Based Social Work, 2013, 10(1): 33-43. https://doi.org/10.1080/154337142013.750551 